Journal

of Geography,

Politics and Society

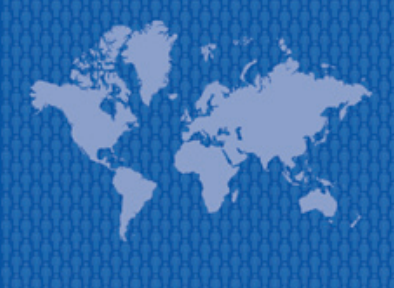

$10(2) / 2020$

\section{Journal of Geography, Politics and Society}

2020, 10(2), 1-9

https://doi.org/10.26881/jpgs.2020.2.01

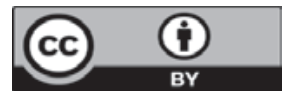

\title{
APPLIED ASPECTS OF HUMAN GEOGRAPHY. A CRITICAL APPROACH TO TRADITIONALIST VIEWS
}

\author{
Valentin Mihaylov \\ Institute of Social and Economic Geography and Spatial Management, University of Silesia in Katowice, Będzińska 60, 41-200 Sosnowiec, Poland, \\ ORCID: 0000-0002-5888-6583 \\ e-mail: valentin.mihaylov@us.edu.pl
}

\section{Citation}

Mihaylov V., 2020, Applied aspects of human geography. A critical approach to traditionalist views, Journal of Geography, Politics and Society, 10(2), 1-9.

\section{Abstract}

Traditionally, applied aspects of human geography are mainly associated with economic geography, regional development and spatial planning.

In the debate on the application potential of the discipline, a number of important problems of social, political and cultural geography, relevant to various contemporary processes on a global and regional scale, are marginalized. For this reason, the author undertakes a critical rethinking of the current debate on the applied aspects of research in human geography.

A brief review of the conceptual and institutional development of applied geography in the world and in selected national schools is made. The author also distinguishes two research orientations: 1) strategic orientation - connected to studies carried out at the international, national and macro-regional spatial levels; 2) operational orientation - concerning applied studies undertook on a scale of separate municipalities, cities, neighbourhoods or even separate streets and buildings.

Taking an attempt to overcome the narrow understandings of the frameworks of applied human geography, the author presents a new definition and tries to identify the main challenges for geographers that work in the field of Human Geography. Applied aspects of basic directions of human geography from the point of view of their broader interdisciplinary ties are also indicated.

\section{Key words}

human geography, practical functions, applied geography, constructive geography.

\section{Introduction}

Reflection on the social functions and the possibilities of applying knowledge generated by geographers in practice accompanies geographical thought at all stages of its development as a modern academic field. As specified by Z. Chojnicki (2010), despite attempts to create applied geography, in terms of practical functions, the discipline still did not go beyond the methodological programs and individual activities of separate scholars.

Applied aspects of human geography and their scope are treated differently in national schools and in the views of individual scientists (Leszczycki, 
1962; Parysek, 1990, 2004; Pacione, 1999, 2011; Chojncki, 2010; Phlipponneau, 2004; Aleksandrova, 2006; Gladkiy, 2010; Anoshko, 2011; Lee, Sui, 2015; Mihaylov, Runge, 2018). For this reason, an attempt to systematize the current priorities in application research in the field of human geography was made in the paper. Moreover, the specificities of selected national schools have been also taken into consideration. This undertaking required a critical look at the previous ways of defining and interpreting categories as applied geography and constructive geography, and the occurrence of certain understatements in categorizing separate geographical studies and publications as "applied" or "fundamental". The author has in mind "non-physical" part of the discipline intentionally specified as human geography. The term socio-economic geography, widely used in Central and Eastern Europe, excludes from the debate a number of important currents of social and economic geography, or at least diminishes their meaning. This is one of the chief accents of the paper. Thus, the author undertakes a critical re-thinking of the current debate on the application aspects of research in the field of human geography. Because of limitations in the volume of papers, some of the author's theses and arguments are presented in a brief manner. The same also concerns the number of references.

This paper focuses on chosen concepts and schools which deal with practical aspects of human geography. Contentious issues in this field are addressed in their formal dimension (e.g. in institutional projects or publications) as well as in backstage disputes and relations of geographers. We can arbitrarily divide these disputes into several groups. Each of them has its own specificity:

1) From the point of view of methodology, studies carried out on the basis of the positivist approach are considered practical. On the other hand, there is a less favourable attitude towards studies based on humanistic methodology which are rarely treated as potentially applicable in real life.

2) From the point of view of social sphere, excessive emphasis is placed on economic and planning issues. The role of cultural or ethnic factors in solving social problems is insufficiently taken into account or depreciated by geographers.

3) From the point of view of the geographical scale, most geographers mainly focus on solving problems on a national or subnational scale, e.g. regions, individual cities, municipalities, with less attention to international questions.

4) From the institutional point of view, it is usually assumed that the results of research in human geography should be promoted among repre- sentatives of public administration, and less often in business or non-governmental organisations.

\section{Conceptual and institutional development of applied geography in the world and in selected national schools}

\subsection{General remarks}

As a science providing practical knowledge, geography has a long history. It dates back to the time when geography was not formally separated as an academic discipline (Lee, Sui, 2015). The very concept of applied geography originates in the late nineteenth century in Great Britain. E.W. Bunbury (1897; in: Pacione, 1999) looks for the roots of the practical function of the discipline at the time of the birth of geography, at the turn of the third and second centuries BC. Measurements of the Earth and cartographic studies conducted by cartographers and mathematical geographers from Alexandria headed by Eratosthenes were of application significance. In the sixteenth century, during the Great geographical discoveries, geographical knowledge was highly valued by rulers and merchants. Part of the generated knowledge still has unquestionable practical significance, especially at a time of rapid spread of new technologies. For example, research of atmospheric phenomena providing reliable information is relevant in the planning and functioning of certain sectors of the economy, in particular agriculture, transport and tourism. However, methods for monitoring and forecasting have been improved. Nowadays, the application significance of human geography is assessed in terms of the possibility of applying research results in contemporary economy, regional policy, land use, in forecasting and managing demographic processes in states and regions.

One of the first attempts to formulate the essence of applied geography belongs to the British geographer A.J. Herbertson (1899). According to him, it is "a specific way of looking at geography, limiting research to one viewpoint. For a businessman it will be an economic viewpoint, for a doctor a climate and demographic viewpoint, and for a missionary it will be an ethical viewpoint" (Pacione, 2011, p. 9). Despite the romantic nature of this approach to the subject of applied geography, it indicates one important thing. It is a research specialisation and approach to problems limited to the practical needs of specific fields of socio-economic life.

Attempts to discuss the essence of practical aspects of human geography or selected threads of its development in selected regions and countries were 
discussed in geographical publications, e.g. in North America (Frazier, 2004), Western and Southern Europe (Gaspar, 2004), Central Europe (Enyedi, 2004), Russia and the former Soviet Union (Gerasimov, 1966; 1992; Sobisevich, Snytko, 2019), Poland (Leszczycki, 1962; Parysek, 1990, 2004; Chojnicki, 2010). The mentioned authors discuss and define the tasks of applied geography and contribute to its conceptualisation and methodological operationalisation.

The institutional form of cooperation in the field of practical aspects of geography is performed by the Applied Geography Commission of the International Geographic Union (IGO). The initiative to create it was taken during the nineteenth IGU Congress in Stockholm in 1960 by M. Phlipponneau (Leszczycki, 1962). The main goals of the IGO applied geography research group include: development and coordination of professional geographers' networks in the field of applied geography; organisation of meetings and publications; establishing cooperation with non-governmental organisations, private companies, and public agencies; ensuring greater employment opportunities for geography graduates in business and government structures. On the commission's website, the contribution of geographers to applied science is highlighted, while it is pointed out that this contribution is not always recognised. To some extent, this is due to the fact that geographical institutions are more effective in meeting the needs of geographers from academic environments than those working in other public institutions or in a private sector (Website of the Applied Geography Commission).

To conclude, summarising studies on specialised literature and author's own practical experience concerning the intensity of contacts between academic geography and practice, the author distinguishes several channels through which geographical knowledge is promoted in various social spheres:

1) Participation of geographers in projects aimed to solve infrastructural, economic and social problems.

2) Participation of geographers in teams defining or conducting specific policies at the local, regional, national or international level. However, it should be recollected that the participation of geographers in various commissions and public administration projects does not necessarily involve the use of geographical knowledge, since educated geographers often have knowledge on legal, financial, or administrative issues.

3) Preparation by geographic teams at the request of ministries and government agencies, local self-governments or NGOs of general or sectoral analyses, spatial evaluations, regional and local development strategies.

4) Participation in investment projects and business plans in a new location (expert evaluation of the local tax system, availability of investment plots, modern business centres, situation on the labour market, transport accessibility, access to raw materials, distance from markets, etc.).

5) Scientific study in the form of an article, book, map, atlas or report, the results of which can be used for practical purposes. The chief controversies and disagreements are raised by the very distinction between scientific works considered practically applicable in socio-economic life and those perceived as strictly academic ones.

\subsection{Applied Geography in Western schools of geography}

In the English-speaking countries, and broadly - in the English-language publications, practical human geography studies are developing under the name of applied geography. This term is used not only as a cognitive category, but it also represents a separate research discipline. In fact, this trend is a loose collection of quantitative works on various topics related to problems of nature as well as ecological, social, and economic development, or application of GIS. Despite the fact that human geography studies have been undertaken on various spatial scales, geographers mainly focus on selected socio-economic problems on an urban, local and regional scale.

In the English-speaking world, the journal Applied Geography, founded in 1981, makes a significant contribution to the development and promotion of practical aspects of the discipline. In the age of globalisation and the expanding dominance of English in international scholarly communication, the possibilities of the journal's influence have increased on a larger scale. Applied Geography publishes the results of studies using a geographical approach to solving specific research problems of human society that have a spatial dimension. The most frequently addressed ones are the assessment, management and territorial distribution of natural or human resources of the world (Website of Applied Geography journal).

M. Pacione, who has published a number of papers in this field, treats applied geography as a research approach in which geographical knowledge and skills are undertaken to solve social, economic and environmental problems. The factor that connects various studies in applied geography is not a specific model or theory, but a fundamental philosophy of their importance or utility for society (Pacione, 2011). The author advocates the concept 
of "useful knowledge" separating pure from applied geographical research. The author is convinced that "some geographical studies are more useful than others". Simultaneously, he asks important questions: available to whom? Who decides about it, and on the basis of what criteria? (Pacione, 2011). Such dichotomous division suggests that theoretical and methodological achievements fall into the category of pure research. Although it is not directly stated, this approach determines which part of the knowledge is "useless" for practitioners. This would mean that creation of a new concept or a development of a new method for spatial analysis by scientists will be treated as "pure knowledge" (implicite - "unuseful"). In turn, the results of application of the same new method by another scientist or practitioner will be considered "practical ('needed', 'useful') knowledge". Therefore, it seems that in this regard the more traditional division into basic (including theoretical) and application (practical) research is more reliable. Reference can be made to Chojnicki's model (2010), which distinguishes two functions of geography in terms of knowledge generation: 1) cognitive functions associated with the progress of research based on detecting, determining and explaining facts; 2) utilitarian functions serve for solving problems of practice related through transformation of reality by constructing projects or planes connected to the subject matter of geography.

Lee and Sui (2015) made a review of the most discussed topics in practical geographical research published in such journals as: The American Association of Geographers Papers in Applied Geography (for 2013), Papers of the Applied Geography Conferences (2007-2012) and Papers and Proceedings of the Applied Geography Conferences (1978-2006). These authors provide an empirical picture of the entire applied geography and human geography in particular, at least in the United States. Physical and human geography are almost evenly represented. In the entire period from 1978 to 2007, the largest percentage of papers were published in the following branches: environmental planning and management, water resources, transport, planning, development, business and retail trade, tourism and recreation. To a large extent, these problems retained their dominance to the middle of the 2000s. The use of new technologies and methods by geographers resulted in the emergence of new trends in the period from 2007 to 2013. The issue of environmental planning and management has maintained a leading position in the structure of published articles. Among the leading topics are also GIS / GPS, environmental threats, planning, economics, education, crime, and remote sensing.

\subsection{Constructive geography in the former USSR and Russia}

In the former Soviet Union, as well as in the states emerged after its decomposition, the concept of constructive geography was developed. This involves the establishment and development of an entire academic school, a number of concepts, publications and conferences.

Looking critically at the most important characteristics of constructive geography and the reasons for its weaknesses, A. Levintov (in: Gladkiy, 2010) mentioned the following arguments: 1) complex mathematical quantitative and graphical methods of analysis; 2) a high degree of abstraction and detachment from the real geographical environment; 3) reducing the geographical environment to productive, recreational or cognitive activities; 4) focusing research on the design and transformation of the geographical environment.

The development of constructive geography is strongly correlated with the establishment of the Institute of Geography of the Siberian Branch of the Russian Academy of Sciences in 1957 with headquarters in Irkutsk. Over the next decades, this Institute carried out a series of studies under the leadership of I. Gerasimov, and later V. Soczava. Till the 1980 s, state authorities and some ministries of the Soviet Union commissioned the Institute to conduct a number of scientific evaluations and specialised research: in the field of transport infrastructure development, reversing the Siberian rivers, research related to the Aral Sea crisis, exploitation of oil fields in West Siberia, construction of hydropower plants, etc.

According to V.M. Kotlyakov and A.A. Tishkov (2008), due to the development of constructive geography in Irkutsk, a "positive hybrid" appeared. This means that the main result of the activity of the Institute of Geography was the optimisation of relations between fundamental and applied studies. Notably, the main feature of constructive geography was based on research programs which combined theoretical, methodological and empirical approaches and methods. These research programs concerned, for example, organisation and management of geographical space, rational use of natural resources and optimisation of relations with the economy and society in conditions of technological progress, rapid urbanisation and industrialisation. The Soviet school developed a comprehensive practical geography project directed to attempts at solving problems of the geographical environment in a comprehensive manner, which required collaboration between economic and physical geographers. As a whole, constructive geography has emphasized fundamental research primarily focusing on the influence of 
socio-economic activities on the geographical environment (Gerasimov, 1982).

It is worth mentioning that in the former USSR physical geography had a definite advantage in applied research. A similar trend also occurs in modern Russian geography. One example can be given here. 28 papers were presented at the conference "The idea of constructive geography and the development of fundamental geographical research", which took place in the city of Kostroma in September 2015. Only seven of them concerned the problems of human geography, including the importance of constructive geography in solving geopolitical problems of Russia, tourism development, agrarian reforms, socio-ecological systems in mountain areas (Naučnaâ..., 2015).

\subsection{Applied aspects of Human Geography in Poland}

In the second half of the twentieth century, the development of applied research also intensified in other countries of the Eastern Bloc. Attempts to problematise and conceptualise the practical aspects of geography in Poland have a relatively long tradition. Unlike the former Soviet Union, the development of geography in Poland puts socio-economic geography in a better position since it is more practical in cognitive terms and has a wider scope of application and richer achievements in practice as well (Parysek, 1990).

Under the influence of Marxist ideology and because of full domination of the state in spatial planning and funding of science, human geography has experienced a revolution in terms of application priorities and internal specialisation. The pre-war human geography / anthropogeography was transformed into economic geography. As M. Kiełczewska-Zaleska (1958) critically pointed out, in the post-war years, economic geography became a new direction which moved away from many currents and disciplines of human geography, and thus narrowed the scope of research activities. This model, despite progress in the structure of the discipline and the process of sociologisation of geographical knowledge, undoubtedly influenced the specifics of practical research in Polish human geography. As noted by J.J. Parysek (2004), the main recipients of the products of geography (including methods and techniques of analysis) are those spheres of social life which deal with shaping structures, organisation and functioning of human living space. Socio-economic spatial planning and spatial management play a primary role in this regard.

Poland is one of the first countries in the former Eastern bloc in which the applied problems of human geography became the subject of compact scientific publications. One of the first issues of the English-language magazine Geographia Polonica (1964) was entitled Problems of Applied Geography. It included works developed as part of the Polish-British seminar in Keele in 1962. Most of them discussed problems of industrialisation, urbanisation and development of small towns.

In contemporary Polish geography, there is an evolutionary change in the scope and role of geographical research (Bański, 2016). The utilitarian functions of geography have been rather underestimated and unused for a long time, while J. Bański points out the tendencies of moving away from theoretical and cognitive issues towards applied research (diagnosis and expertise) ordered by various governmental and local self-government institutions.

J.J. Parysek (2004) specified that in strictly geographical matters, geographers are displaced from their field of competence by economists, sociologists, architects, political scientists, lawyers and representatives of other disciplines. The author justified this unfavourable tendency by the fact that after environmental issues and tourism geographers give other disciplines other spatial issues, i.e. regional and local economy, territorial planning and shaping of living environment. Undoubtedly, this is a universal problem that concerns not only human geography in Poland.

\section{Thematic and methodological asymmetry in applied human geography research}

\subsection{Research scale}

Fig. 1 shows a generalised model of applied human geography and highlights its structural and methodological peculiarities. The author proposes an arbitrary division according to the following criteria: scientific orientation (divided by a strategic and operational level), socio-economic sphere with its macro and micro levels, and spatial scale.

Most of strategic research undertaken on a larger geographical scale concerns such problems as sustainable development, elaborations of characteristics and recommendations on the optimisation of the functioning of international or national transport corridors, concepts of spatial development of countries, studies on the settlement network system, etc. This type of research is often undertaken by scholars from Central and Eastern European countries, although their scale is limited mainly to separate countries or their regions. There are, certainly, exceptions in which geographers actively took part in the practical implementation of investments on 


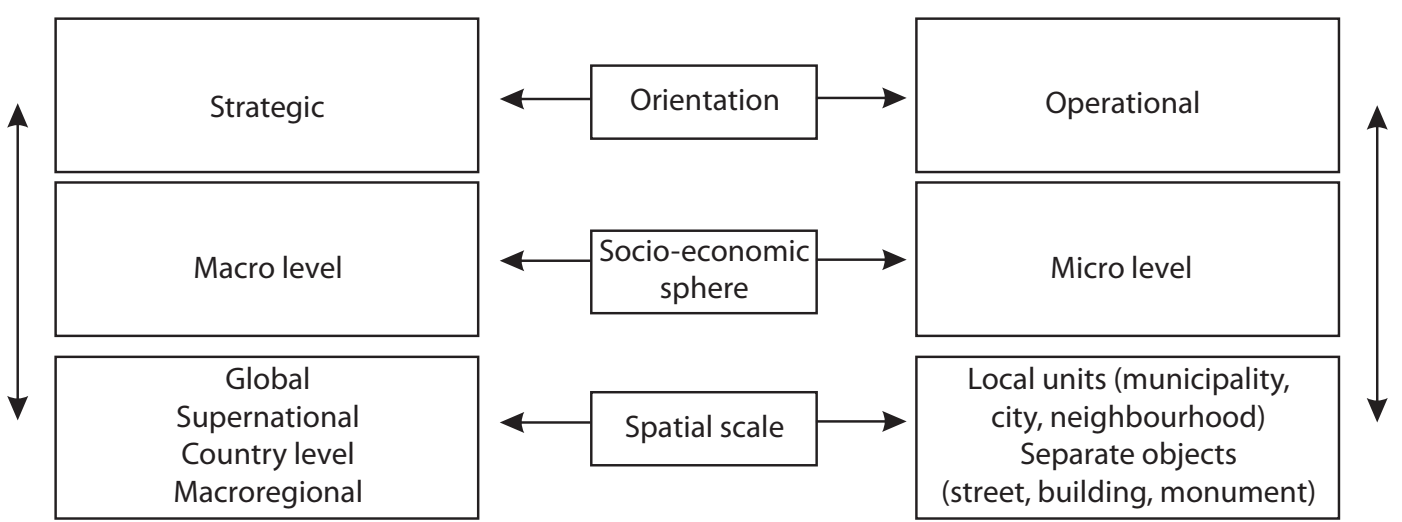

Fig. 1. Generalised model of research in applied human geography

Source: Author's elaboration.

a smaller spatial scale merging strategic and operational research. The list of outstanding achievements may not be long, but there are individual examples as the construction of a new waterway (canal) between Varna and Devnia, west of the Varna Bay in Eastern Bulgaria in the 1970s. The geographer A. Beshkov who comes from this city, was the first who proposed the idea of building the waterway and a new port, justifying its location (Beshkov, 1957; 1959). Based on this strategic investment, the so-called industrial agglomeration of Varna - Beloslav - Devnia, including five ports and several large industrial plants, was established.

The potential list of applied research on a micro scale is much broader in terms of the scope of problems. These studies may concern, among others, changes in the structure of land use in settlements, elaboration of models for optimisation of the public transport in urban agglomerations, development of infrastructure in special economic zones, and revitalisation of downtown districts, post-industrial or residential areas. Traditionally, the research on a micro scale aimed to generate knowledge which is potentially useful in specific operational activities was more often undertaken by Western geographers (for instance: Lee, Sui, 2015). In turn, for human geography in former communist countries, many strategic studies were often too general and abstract; therefore, they had little chance to be directly applied in a socio-economic life. As already noted, the excessive focus on the large-scale problems and the lack of a clear specialisation of constructive geography in the former Soviet Union led to the crisis of this discipline. However, in the age of globalisation and more intensive internationalisation of scientific research, these differences are slowly blurring.

\subsection{Favouritism for reasons of methodological perspective and thematic specialisation}

Taking into account philosophical and methodological criteria, the disputes between supporters of the positivist or the humanistic approach concern the applied importance of one or another performed study. Regarding the methods used, the strong and weak points of quantitative and qualitative research are traditionally the most discussed aspects. Studies carried out by applying quantitative methods are often accepted a priori as applicable. This applies to both the attitude of reviewers of scientific articles and books, doctoral theses, applications for project funding as well as the policy of decision-making bodies (Department Council, Faculty Council, various thematic committees, scientific societies, etc.). The very appearance of quantitative methods in a scientific work, i.e. mathematical and statistical models, encourages evaluators to treat this work as "applied". Such a state of affairs occurs in various cases, regardless of whether it is about political geography (in the case of parametric assessment of the power of states), economic geography (employment level or the dynamics of production) or geodemography (life expectancy calculations).

Common opinions about the practical significance of works created in human geography depend on subjective factors, thematic specialisation, and particular interests of individual scholars. According to unwritten rules, the practical value of a given geographical work can often be assessed only on the basis of its specialisation. Wherein, analyses related to economics and planning are usually treated favourably in terms of their practical value. It concerns research in traditional directions, i.e. agricultural, industrial and service geography, transport geography, geographical aspects of the labour market. Studies on regional policy, spatial management, territorial planning and regional development are 
undertaken more and more often from an interdisciplinary perspective. Studies conducted in this fields combine perspectives and a method of economic geography, economics, management sciences and urban planning. The main purpose of geographers' research in these directions is to conduct evaluation in human - economy - environment relations, development of forecasts and proposals of specific measures aimed at their spatial optimisation, which will meet the specific needs of society. M. Hilpert (2002), G. Raagmaa (2002), V. Mihaylov \& J. Runge (2018), K. Zimmerbauer (2018) and other authors wrote about the possibilities of using te humanistic perspective in geography to obtain results of importance for practice. Despite this, recognition of works with social or cultural content meets with greater resistance from many conservative scientists. It is no secret that such situations occur during discussions on the choice of subjects for MA or PhD theses. This is due to many scholars' belief that if the author undertakes issues related to spatial planning, the labour market or economic investment, his work is automatically granted with practical significance.

All these circumstances influence not only the image of human geography in a society. As indicated in previous parts, the scope of the above-mentioned spheres of social life in which geographers really have something to say is also narrowing. Moreover, social or cultural threads still represent a modest share in the works of university graduates, including $\mathrm{PhD}$ theses. What is more, geographers hardly ever propose solutions that could find application in such fields as diplomacy, international relations, national or international security, or ethnopolitical conflicts. Publications of similar themes rarely appear in journals specialised in strictly geographic matters.

In this respect, a large difference is noticeable in comparison to the beginning of the twentieth century. This was a crucial time for re-ordering of geopolitical structures and relations. Then, the ideas of the most outstanding representatives of geography from various nations, especially from Central Europe and the Balkans, participated in and had a real influence on shaping the political order. For example, in 1913, a geographer Anastas Ishirkov was a member of the Bulgarian delegation at the conference in Bucharest after the Second Balkan War. As M. Górny (2013) noted, during the negotiations in Versailles, Saint-Germain-en-Laye, Neuilly-sur-Seine, Trianon and Sèvres after the First World War there were also geographers from both victorious powers and newly created states. The interests of the French side were represented by Emmanuel de Martonne, Emmanuel de Margerie, Albert Demangeon, Lucien Gallois and Jean Brunhes. In turn, Jovan Cvijić, during the
Versailles conference, was a member of the Serbian delegation. The Polish side was represented by Eugeniusz Romer. These geographers were playing a key role in the work of territorial commissions. After the Second World War, the outstanding Polish geographer and chairman of the International Geographical Union, Stanisław Leszczycki, was an energetic propagator of "the application of geographical research to practical purposes" (Leszczycki, 1962). S. Leszczycki participated as an expert in the Polish delegation that negotiated the final course of the Polish-Soviet border in Moscow in 1945 (Eberhardt, 2018).

\subsection{Author's concept of applied human geography}

Human geographers often complain that the results of their research are rarely recognised or at least hardly visible in the social, political and economic life, and even that a great deal of the generated geographical knowledge is of little use for modern society. Disagreeing with such a widespread, too far-reaching opinion, a few general geographical methods and technics which are widespread and commonly used in social life could be mentioned: the cartographic method and the geographical map which is the final result of its use - an object of everyday use by millions of people; method of regionalisation of the territory (with separation of complex or sectoral regions); a scheme of a comprehensive geographical description of a territory (an inseparable element of each plan or strategy for spatial development of administrative units); GIS, etc.

Among geographers, it is often assumed that the use of more or less complex operations to calculate empirical data automatically gives the published results as a book, article or report an applied essence. The author of this paper is of the opinion that, as long as the results of this study are not implemented in life, we can only speak of their application potential. It is, therefore, worth separating two categories: - first - studies that have already been applied in practice, and

- second - study results with a potential to be applied, which are not equal to the first category. The first category concerns geographical studies and their results, ideas, concepts, methods and research tools that have already been used for certain practical purposes; specific works and geographical expertise applied in practice (in spatial management or in the labour market, tourism and recreation, geopolitics, in the protection of cultural heritage, etc.).

In the paper, some limitations that brake the separation of the common application potential of human geography were indicated. In the future, 
in order to increase the impact of their research in practice, geographers should undoubtedly consider new topics and problems in relations between society and space. Therefore, the author proposes the following definition of applied geography: a current in human geography, which includes research generating propositions for changes in the state of certain phenomena, structures, relationships, movements, flows in their spatial dimension, in order to increase the quality of human life and optimise relations with both natural and anthropogenic environments.

Unlike other concepts and definitions on the subject, this approach does not limit practical geographical research exclusively to spatial and economic issues or engineering activities aimed to transform and physically modify the current land use condition of a given area, as it was in constructive geography. The positive effects of such an approach may also include citizens' increased awareness of social, cultural or ecological problems of their neighbourhood, city or region (for example: Hilpert, 2002).

Considering the above presented concept, several proposals can be made for further development and diversification of applied research in the field of human geography:

1) Continuation of previous research related to the economy and spatial planning, industry, agriculture, transport and tourism, including an improvement of their theory and methodology.

2) Increasing geographers' awareness of the wider applied potential of human geography, which is not limited to directions of economic geography.

3) Extending geographers' cooperation with institutions other than those specialised in spatial planning and regional policy - e.g. in the field of diplomacy, international relations, security, resolutions of territorial and ethnonational conflicts.

4) Attitude change by political and cultural geographers is necessary to prepare a part of their research in a way giving possibilities for application in the activities of specific public institutions, $\mathrm{NGOs}$ or private companies.

\section{Closing remarks}

Based on selected publications in geographical literature analysed during the preparation of this paper, we may conclude that a variety of opinions about the practical importance of human geography research exists. There is some agreement between scientists that studies in the field of economic geography and spatial planning, especially those embedded in quantitative methods, perform leading functions in this respect. Simultaneously, because of excessive emphasis on spatial-economic issues, cultural factors in solving social and political problems are underestimated.

In addition, there is a tendency to give geographical research and methods a secondary function in the process of spatial planning and development. This role is more than once limited to collection and analysis of data for public institutions or business companies, eventually to formulate certain recommendations for regional and local administration.

According to the author of this article, each research that generates new knowledge has an applied potential. It is about the possible application of research results in the future in a given sphere of social, economic or political life. These spheres also include fundamental science and education which shape our worldview, affects our behaviour and our relationships with other people in geographical space.

\section{References}

Aleksandrova T.D., 2006, Ot prikladnoj i konstruktivnoj geografii k geoekologii (Eng. From applied and constructive geography to geoecology), Problemy regionalnoj ekologii, 1, 2-6.

Anoshko V.S., 2011, Prikladnaâ geografiâ (Eng. Applied geography), Vyšejšaâ škola, Minsk.

Bański J., 2016, Rozważania na temat stanu i perspektyw geografii w Polsce (Eng. Considerations on the state and prospects of geography in Poland), [in:] A. Suliborski (ed.), Stan, perspektywy i strategia rozwoju geografii społecznoekonomicznej w najbliższych latach (do 2030 r.). Dyskusja międzypokoleniowa (Eng. The state, prospects and strategy for the development of socio-economic geography in the coming years (until 2030). Intergenerational discussion), Wydawnictwo Uniwersytetu Łódzkiego, Łódź, 107-115.

Beshkov A., 1959, Za efektivnostta na kanala Varna - Reka Devnâ (Eng. About the efficiency of the Varna - Devnya River canal), Izvestiâ na B"Igarskoto geografsko družestvo, 2(12), 103-110.

Beshkov, A., 1957, Za promišlenite pristaniŝta Šabla i Devnâ (Eng. On the industrial ports of Shabla and Devnya), Izvestiâ na Geografskâ institut, 3, 47-63.

Chojnicki Z., 2010, Koncepcje i studia metodologiczne i teoretyczne w geografii (Eng. Concepts and methodological and theoretical studies in geography), Bogucki Wydawnictwo Naukowe, Poznań.

Eberhardt P., 2018, Formowanie się polskiej granicy wschodniej po II wojnie światowej (Eng. Formation of the Polish eastern border after World War II), Dzieje Najnowsze, 20(2), 87-118. doi: 10.12775/DN.2018.2.05

Enyedi G., 2004, Applied geography in Central Europe, [in:] A. Bailly, A.J. Gibson (eds.), Applied Geography. A World Perspective, Springer, Dordrecht, 169-185. 
Fraizer J.F., 2004, Applied geography in 20th century North America: A perspective. [in:] A. Bailly, A.J. Gibson (eds.), Applied Geography. A World Perspective, Springer, Dordrecht, 187-210.

Gaspar J., 2004, Applied geography in Western and Southern Europe, [in:] A. Bailly, A.J. Gibson (eds.), Applied Geography. A World Perspective, Springer, Dordrecht, 151-168.

Geographia Polonica, 1964, vol. 3, Problems of applied geography II: proceedings of the Anglo-Polish Seminar, Keele, September 9-20, 1962.

Gerasimov I.P., 1966, Konstruktivnaâ geografiâ: celi, metody, rezultaty (Eng. Constructive geography: goals, methods, results.), Izvestiâ Vsesoûznogo geografičeskogo obŝestva, vol. 5 (no 98), 389-403.

Gerasimov I.P., 1982, Vklad konstruktivnoj geografii v problemu optimizatsii vozdejstviâ obŝestva na okružaûŝuû sredu (Eng. Contribution of constructive geography to the problem of optimisation the impact of society on the environment), Izvestiâ Vsesoûznogo geografičeskogo obŝestva, vol. 114 (no 3), 193-201.

Gladkiy Yu.,N., 2010, Gumanitarnaâ geografiâ / Naučnaâ eksplikaciâ (Eng. Humanitarian Geography / Scientific Explication), Filologicheskij fakultet Sankt-Peterburgskogo gosudarstvennogo universiteta, Sankt-Peterburg.

Górny M., 2013, „Futurystyczna geografia”. Rola geografów w kształtowaniu granic Europy ŚrodkowoWschodniej i PołudniowoWschodniej w latach 1914-1920 (Eng. “Futuristic geography". The role of geographers in shaping the borders in East-Central and South-Eastern Europe in 1914-1920), Studia z Dziejów i Europy ŚrodkowoWschodniej, 48, 117-139. doi: 10.12775/SDR.2013.06

Hilpert M., 2002, Applied Social Geography: Management of spatial planning in reflective discourse. Research perspectives towards a 'theory of practice', Dela, 18, 29-40.

Kiełczewska-Zaleska M., 1958, O kierunkach rozwoju geografii człowieka w Polsce (Eng. On the directions of development of human geography in Poland), Przeglad Geograficzny, vol. XXX, 403-419.

Kotlyakov V.M., Tishkov A.A., 2008, Vektory prošlogo i sovremennogo razvitiâ akademičeskoj geografii. K 90-letiû Instituta geografii RAN (Eng. Vectors of the past and modern development of academic geography. To the $90^{\text {th }}$ anniversary of the Institute of Geography of the Russian Academy of Sciences), Vestnik Rossijskoj Akademii Nauk, vol. 78 (no 9), 810-819.

Lee J., Sui, D., 2015, From Applying Geography to Applied Geography, Papers in Applied Geography, 1(1), 1-7. doi: 10.1080/23754931.2015.1009282

Leszczycki S., 1962, Geografia stosowana czy zastosowanie badań geograficznych dla celów praktycznych (Eng. Applied geography or application of geographical research for practical purposes), Przegląd Geograficzny, vol. 34 (no 1), 3-23.

Mihaylov V., Runge J., 2018, Potencjał aplikacyjny badań nad tożsamością terytorialną (Eng. An applied potential of studies on territorial identity), Rozwój Regionalny i Polityka Regionalna, 43, 53-70.

Naučnaâ programma "Idei konstruktivnoj geografii i razvitie fundamental'nyh geografičeskih issledovanij" 24-27 sentâbrâ 2015 g. g. Kostroma (Scientific program "Ideas of constructive geography and the development of fundamental geographical research", 24-27 September 2015. Kostroma), 2015, www.iaas.nas.gov.ua/Structure/Councils/GeographicalProblems/20150924/Documents/Programme_19.pdf (accessed 10 June 2018).

Pacione M., 1999, In pursuit of useful knowledge: the principles and practice of applied geography, [in]: M. Pacione (ed.), Applied Geography: principles and practice An Introduction to useful research in physical, environmental and human geography, Routledge, London - New York, 3-18.

Pacione M., 2011, Applied Geography: Principles and praxis, Hrvatski Geografski Glasnik, vol. 74 (no 1), 7-28.

Parysek J.J., 1990, Czy i jak geografia pełni funkcje praktyczne - dwugłos nauki i praktyki (Eng. Whether and how geography performs practical functions - a dual voice of science and practice), Przegląd Geograficzny, vol. 62 (no $1-2), 3-21$.

Parysek J.J., 2004, Praktyczne funkcje polskiej geografii (Eng. Practical functions of Polish geography), [in:] Z. Chojnicki (ed.), Geografia wobec problemów teraźniejszości i przyszłości (Eng. Geography towards the problems of present and future), Bogucki Wydawnictwo Naukowe, Poznań, 119-132.

Phlipponneau M., 2004, Historical foundations of applied geography, [in:] A. Bailly, A.J. Gibson (eds.), Applied Geography. A World Perspective. Springer, Dordrecht, 47-67.

Raagmaa G., 2002, Regional identity in regional development and planning. European Planning Studies, 10(1), 55-76. doi: 10.1080/09654310120099263

Sobisevich A.V., Snytko V.A., 2019, Konstruktivnaâ geografiâ: naučnoe napravlenie o preobrazovanii prirodnoj sredy (Eng. Constructive geography: a scientific direction on the transformation of the natural environment), [in]: Sbornik trudov Meždunarodnoj naučnoj konferencii "Steny i mosty VII" (Eng. Proceedings of the International Scientific Conference "Walls and Bridges VII"), RGGU, Moskva, 245-251.

Website of Applied Geography journal. www.journals.elsevier.com/applied-geography (accessed 22 March 2017).

Website of the Applied Geography Commission. https:// agcigu.wordpress.com/ (accessed 13 May 2017).

Zimmerbauer K., 2018, Supranational identities in planning, Regional Studies, Vol. 52 (no 7), 911-921. doi: 10.1080/00343404.2017.1360481 